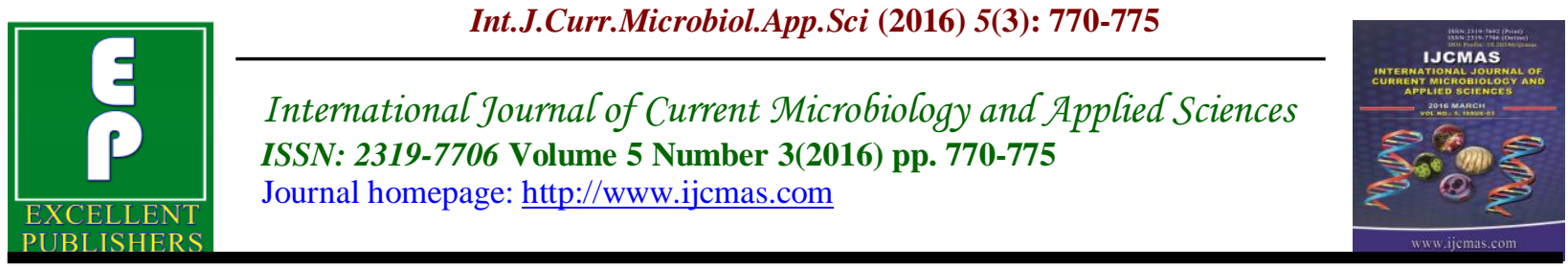

Original Research Article

http://dx.doi.org/10.20546/ijcmas.2016.503.089

\title{
Determination of the Quality of Lukha River, Meghalaya on the Basis of Physicochemical and Microbiological Parameters
}

\author{
Anisha Gogoi, Aibanjoplang Hujon, Mc Kinnel Mann Lyngwi and Jeremy Nelson Syiem*
}

Department of Biotechnology \& Biochemistry, St. Anthony’s College, Shillong, Meghalaya, India

*Corresponding author

\begin{abstract}
A B S T R A C T
Keywords

Lukha river,

Physicochemical

parameters,

Coliforms,

Most Probable

Method,

Microbiological

indicator.

Article Info

Accepted:

20 February 2016

Available Online:

10 March 2016

The Lukha river is one of the major rivers flowing East Jaintia Hills, Meghalaya. It is the main source of drinking water for the people inhabiting its banks. In this study, analysis of a portion of the river flowing through Sonapur village, East Jaintia Hills District, Meghalaya, which is one of the major populated villages situated on its banks, was carried out. The physicochemical parameters analysed were Dissolved Oxygen, BOD, COD, $\mathrm{pH}$, temperature, Total hardness and Calcium hardness. An estimation of coliforms which are microbiological indicators of water pollution was also done by the Most Probable Number (MPN) method. The physicochemical results were within the WHO standards while the coliform count was above the set limits. This showed the presence of faecal contamination in the river water which may pose a threat to the health of the people in the area.
\end{abstract}

\section{Introduction}

Fresh water in the form of rivers and streams is the major source of drinking water for humans. It is also used for other washing and other purposes. The rise in human population and the ensuing anthropogenic activities have however put these pristine "elixirs" of life in danger of either running dry or becoming unfit for human use. The dumping of sewage, domestic and industrial as well as agricultural run-off has led to the pollution of most rivers in the world (Agbabiaka and Oyeyiola, 2012).
This not only affects the ecosystem of the rivers but also animal and human health. The use of polluted water has a huge impact on the health of children especially in the developing countries where it is estimated that most of the two million people who die annually due to enteric diseases are children below the age of 5 (Bello et al., 2013).

In this study, the Lukha river, which flows through the East Jaintia Hills District of Meghalaya was taken into consideration as it 
is one of the important sources of drinking water for the people of the surrounding region. Analysis of the degree of pollution of the river water was based on certain physicochemical parameters like $\mathrm{pH}$, temperature, Dissolved Oxygen (DO), Biochemical Oxygen demand (BOD), Total hardness, Calcium hardness and Magnesium hardness as well as the presence of coliforms. These physicochemical features are very important sustaining the health of an aquatic ecosystem (Ibrahim et al., 2009; Mbalassa et al., 2014). Of all these parameters, DO is the most important as it provides information regarding the productivity, microbial activity, nutrient availability etc of an aquatic system (Patil et al., 2012).

DO values give an estimate of the rate of microbial decomposition of organic wastes. A reduction in the DO of a water body could be due to bioaccumulation and eutrophication. The temperature of water also plays an important role in the regulation of all biotic functions as well as physicochemical features (Sabae et al., 2014). The measurement of BOD lets us know the amount of oxygen that is being used up by microbes to degrade organic waste. The higher the BOD value, the lesser will be the $\mathrm{DO}$ value and vice versa. $\mathrm{pH}$ on the other hand has no direct impact on human health except that it changes the taste of water and at the same time it may lead to the formation of trihalomethanes which are toxic (Mostafa et al., 2013).

Hardness of water is the measure of the total concentration calcium and magnesium ions expressed as calcium carbonate. Calcium hardness can be measured independently of total hardness as Calcium is usually found in high concentrations in water due to leaching from lime stone deposits, gypsum deposits etc. Although hardness has no effect on human or animal health, it is essential in the removal of toxic components in the water.

Coliforms are considered to be microbiological indicators of water pollution (Sabae et al., 2014). These bacteria mostly belong to the family Enterobacteriaceae and include Escherichia coli, Enterobacter aerogenes, Klebsiella sp. etc. Most coliforms are found in the intestinal tract of warm-blooded animals and enter the outside environment through the fecaes of these animals (Thakur et al., 2012; Mostafa et al., 2013). These bacteria may not all be pathogenic themselves but serve as indicators of the presence of more pathogenic micro-organisms which may also be present in animal faeces. Water contaminated by these pathogens may be ingested by humans which will lead to the occurrence of various enteric diseases (Saha et al., 2012). To determine the presence and number of coliforms in Lukha river, the Most Probable Number (MPN) method was used (Sutton, 2010; Kumar et al., 2013; Dadwal et al., 2014). This method will provide information regarding the extent of faecal contamination of the river.

\section{Materials and Methods}

\section{Sampling}

Sampling was done at two sites of the Lukha river that flows through the populated village of Sonapur. These two sites were designated as Upstream (US) and Downstream (DS) and were located at the beginning and end of the village perimeter respectively.

\section{Analysis of Physicochemical Parameters}

Physicochemical parameters like DO, temperature and $\mathrm{pH}$ were measured in-situ. For the measurement of the other physicochemical parameters, water sample was collected in sterile, clean sample 
containers, stored at $4^{\circ} \mathrm{C}$ and taken to the laboratory for further analysis as per the American Public Health Association (APHA, 2012) guidelines.

\section{Most Probable Number Method}

For carrying out the MPN test, water sample from the sites US and DS was collected in sterile containers and taken to the laboratory for analysis. The MPN method consisted of three stages namely, the presumptive test, the confirmed test and the completed test (Harley and Prescott, 2002).

\section{The Presumptive Test}

In this test, 3 double strength lactose broth tubes were inoculated with $10 \mathrm{ml}$ of the water sample, 3 single strength broth tubes were inoculated with $1 \mathrm{ml}$ of the water sample and 3 single strength lactose broth tubes were inoculated with $0.1 \mathrm{ml}$ of the sample.

Durham's tubes were placed in the broth tubes to check for the production of gas. Incubation of the tubes was done at $35^{\circ} \mathrm{C}$ for 24 to 48 hours. The number of coliforms was then estimated after incubation based on the three tube MPN test table from FDA's Bacterial Analytical Manual (Sutton, 2010).

\section{The Confirmed Test}

A loopful of inoculum from a tube containing maximum gas production in the presumptive test was aseptically transferred into a brilliant-green lactose bile broth tube containing a Durham's tube. Incubation was carried out at $35^{\circ} \mathrm{C}$ for 48 hours to check for the production of gas.

\section{The Completed Test}

Inoculum from a brilliant-green lactose bile broth tube showing gas production was streaked onto Eosin Methylene Blue (EMB) agar plates. Colonies with a metallic green sheen growing on these plates were then inoculated into brilliant-green lactose bile broth tubes again to check for gas production. Gram staining was also performed to determine the shape and cell wall constitution of the bacteria.

\section{Results and Discussion}

\section{Physicochemical Parameters}

The results obtained for the physicochemical parameters from both the sampling sites US and DS were quite similar as shown in Table 1. The results were compared against the standards for drinking water set by the World Health Organization (WHO, 1998) and found to be within the acceptable range.

\section{MPN Method}

The presumptive test showed all lactose broth tubes to contain gas. From the three tube MPN test table of the FDA, the most probable number of coliforms was estimated to be more than 1100 per $100 \mathrm{ml}$ of the sample. This value was much higher than the recommended MPN value for drinking water which is 50 or less / $100 \mathrm{ml}$ ( CPCB, 2008) The confirmed and completed tests yielded results which were true for coliforms. Colonies with metallic green sheen were observed in EMB agar and gram staining revealed the bacteria to be Gram negative bacilli. These are characteristic features of coliforms. 
Table.1 Physicochemical Parameters Recorded from Lukha River Sampling Sites US and DS

\begin{tabular}{|c|c|c|c|c|c|c|c|}
\hline \multirow{2}{*}{$\begin{array}{c}\text { Sampling } \\
\text { sites }\end{array}$} & $\begin{array}{c}\text { Temp } \\
\cdot\left({ }^{\circ} \mathbf{C}\right)\end{array}$ & $\mathbf{p H}$ & $\begin{array}{c}\text { DO } \\
(\mathbf{m g} / \mathbf{L})\end{array}$ & $\begin{array}{c}\text { BOD } \\
(\mathbf{m g} / \mathbf{L})\end{array}$ & $\begin{array}{c}\text { Total } \\
\text { Hardnes } \\
\mathbf{( m g / L )}\end{array}$ & $\begin{array}{c}\text { Calcium } \\
\text { Hardness } \\
(\mathbf{m g} / \mathbf{L})\end{array}$ & $\begin{array}{c}\text { Magnesium } \\
\text { Hardness } \\
(\mathbf{m g} / \mathbf{L})\end{array}$ \\
\hline US & 28.5 & 7.4 & 8 & 2.5 & 100 & 60 & 40 \\
\hline DS & 27.6 & 7.4 & 8.4 & 3.9 & 110 & 60 & 50 \\
\hline $\begin{array}{c}\text { WHO } \\
\text { standards }\end{array}$ & $30-32$ & $6.5-8.5$ & 7.5 & 6.9 & 200 & - & - \\
\hline
\end{tabular}

In the present study, the physicochemical parameters of the two sampling sites at the Lukha river were found to be within the acceptable limits (WHO, 1998) even though Sonapur village through which the river flows was quite populated and was situated along the National Highway. This could be due to the sampling period which was done in the month of September just after the Monsoon. The heavy monsoon rains which are quite common in these regions may have washed any pollutants further downstream. The presence of a high MPN of coliforms however indicated the presence of faecal contamination which could be due to the disposal of animal and human faeces directly into the river water as reported by Frimpong et al., 2015. Also the type of organic waste that enters the water could be another factor for influencing the microbial flora that thrive there (Sumanpouw and Risjani, 2014). The physicochemical parameters found in Lukha river during the time of study also seem to favour the microbial growth. This was also reported by Igbinosa et al, 2012 on their work in the Nigeria Delta. Amongst the coliforms, $E$. coli is the most common to be found as reported by Ekhaise and Omoigberale, 2011. However other non coliforms may also give a false result in the presumptive test which therefore makes it mandatory to carry out the confirmed and completed tests (Shreshta and Sujakhu, 2014). In the end, it is important to keep a constant monitoring programme of rivers so that they can be free from contamination by pathogenic microbes (Chowdhury et al., 2013). The guidelines for such monitoring programmes and subsequent analysis of water have been formulated by agencies like the WHO, APHA and others (Edet et al., 2012) can be made available to the local authorities concerned in the study area or any other area in which rivers, streams, ponds or lakes are present so as to prevent degradation of the water body and infection of humans by water borne pathogens.

\section{Acknowledgement}

The authors would like to thank the University Grants Commission, New Delhi for providing financial assistance to this study through its "Minor Research Project" scheme. Also, the authors would like to thank Br. Albert L. Dkhar, Principal, Dr. M. A. Laskar, Head, Deptt. of Biotechnology and Dr. H. G. Lyngdoh, Head, Deptt. of Biochemistry, St. Anthony's College, Shillong, Meghalaya for their kind help and encouragement. Great thanks also goes to Mr. T. Challam, Deptt. of Biotechnology \& Biochemistry, St. Anthony's College for going out of his way to help us in this study especially in the field trips. Finally, sincere thanks goes to the local people of Sonapur who have been very cooperative and helped us in collecting the water samples. 


\section{References}

Agbabiaka, T.O., Oyeyiola, G.P. 2012. Microbial and Physicochemical Assessment of Foma river, Itanmo, Ilorin, Nigeria; an important source of Domestic water in Elorin Metropolis. Int. J. Plant Ani. Envt. Sc., 2(1): 209-216.

APHA. 2012. Standard Methods for the Examination of Water and Wastewater. American Public Health association, American Water Works Association and Water Environment Federation. $22^{\text {nd }}$ Ed.

Bello, O.O., Osho, A., Bankole, S.A., Bello, T.K. 2013. Bacteriological and Physicochemical Analysis of Borehole and Well water sources in Ijebu-Oda, Southwestern Nigeria. IOSR J. Pharm. Bio. Sci., 8(2): 1825.

Chowdhury, M.H., Saha, P., Haque, S.M.E., Fuadh-Al-Kabir, Md. 2013. Seasonal Variation in Physicochemical and Microbial parameters in treated River water from Bangladesh. Int. J. Pure Appl. Sci. Technol., 17(1): 1121.

Central Pollution Control Board (CPCB). 2008. Guidelines for Water Quality Management. CPCB.

Dadwal, J., Bhatnagar, A., Kumar, S. 2014. Assessment of Physicochemical and Bacteriological parameters of Sukhna Lake in Chandigarh, India. Int. J. Sci. Res., 3(9): 751-755.

Edet, E.J., Etim, E.E., Titus, O.M. 2012. Bacteriological and Physicochemical Analysis of Streams water in Nduetong Oku Community, Uyo, Akwa Ibom state, Nigeria. Int. J. Mod. Chem., (1): 65-73.

Ekhaise, F.O., Omoigberale, M.O. 2011. Bacteriological and Physicochemical Qualities of Ebutte river in Ebutte
Community, Uhunmwonde Local Government Area, Edo state, Nigeria. J. Appl. Sci. Envt. Management, 15(4): 663-673.

Frimpong, J.O., Amoaka, E.E., Nkoom, M. 2015. Assessment of the Physicochemical and Microbial Quality of water in Ke-Nya stream at Babato-Kuma community in the Kintampo North Municipal Assembly of Brong Ahafo Region of Ghana. Int. J. Sci. Tech. Res., 4(6): 405-411.

Harley, J.P., Prescott, LM. 2002. Laboratory Exercises in Microbiology. $5^{\text {th }}$ Ed. Mc Graw- Hill Companies. pp. 285288.

Ibrahim, B.U., Auta, J., Balogun, J.K. 2009. An Assessment of the PhysicoChemical Parameters of Kontagora Reservoir, Niger state, Nigeria. Bayero J. Pure Appl. Sci., 2(1): 6469.

Igbinosa, E.O., Uyi, O.O., Odjadjare, E.E., Ajuzie, C.U., Orhue, P.O., Adewole, E.M. 2012. Assessment of Physicochemical qualities, heavy meta concentrations and Bacterial pathogens in Shanomi Creek in the Niger Delta, Nigeria. Afr. J. Envtl. Sci. Tech., 6(11): 419-424.

Kumar, R.S., Roymon, MG., Ipe, J.A. 2013. Isolation, Biochemical and Molecular Characterization of strains of Coliforms from the water sample collected from Shivnath River. Rec. Res. Sci. Tech., 5(2): 57-63.

Mbalassa, M., Bagalwa, J.J.M., Nshombo, M., Kateyo, M.E. 2014. Assessment of Physicochemical parameters in relation with fish ecology in Ishasha river and Lake Edward, Albertine Rift Valley, East Africa. Int. J. Curr. Microbiol. Appl. Sci., 3(6): 230-244.

Mostafa, A.H., Al-Wasify, R.S., Sayed, A.M., Haroun, B.M. 2013. 
Microbiological and Physicochemical Evaluation of Groundwater in Egypt. Int. J. Envt. Sus. 2(2): 1-10.

Patil, P.N., Sawant, D.V., Deshmukh, R.N. 2012. Physico-chemical parameters for testing of Water - A review. Int. J. Envt. Sci., 3(3): 1194-1207.

Sabae, S.Z., El-Sheekh, M.M., Khalil, M.A., Elshouny, W.A.E., Badr. H.M. 2014. Seasonal and Regional Variation of Physicochemical and Bacteriological Parameters of Surface Water in WlBahr El-Phenroy, Menoufia, Egypt. W. J. Fish Mar. Sci., 6(4): 328-335.

Saha, M.L., Nessa, M., Khan, M.R., Islam, M.N., Hoque, S. 2012. Bacteriological and Physicochemical Water Quality of Four Ponds of Dhaka Metropolis. Bangladesh J. Bot., 41(1): 55-60.

Shrestha, U.T., Sujakhu, H. 2014. Coliform and Vibrio cholera Analysis of Drinking water collected from Cholera Outbreak Region of
Bhaktapur Municipality. Int. J. Env., 3(3): 139-145.

Sumampouw, O.J., Risjani, Y. Bacteria as Indicators of Environmental Pollution: Review. Int. J. Eco., 4(6): 251-258.

Sutton, S. 2010. The Most Probable Number Method and its Uses in Enumeration, Qualification, and Validation. J. Val. Tech., 16(3): 35-38.

Thakur, M., Negi, S., Kumar, A., Patil, S., Kumar, A., Sharma, N. 2012. Prevalence and Characterization of Water Contamination Indicator Bacteria with Special Reference to Coliforms from Drinking Water Supply in Solan City of Himachal Pradesh. Bio. For. An Int. J., 4(1): 85-89.

World Health Organization (W.H.O). 1998. Guidelines for drinking water quality. Health criteria and other supporting information. $2^{\text {nd }}$ Ed. Geneva. pp. 231-270.

\section{How to cite this article:}

Anisha Gogoi, Aibanjoplang Hujon, Mc Kinnel Mann Lyngwi and Jeremy Nelson Syiem.2016. Determination of the Quality of Lukha River, Meghalaya on the Basis of Physicochemical and Microbiological Parameters.Int.J.Curr.Microbiol.App.Sci. 5(3): 770-775. doi: http://dx.doi.org/10.20546/ijcmas.2016.503.089 